\title{
Introduction:
}

\section{TOWARDS AN EXPANDED CONCEPT OF ISLAND STUDIES}

[DOI: 10.21463/shima.10.1.03]

\author{
PHILIP HAYWARD \\ Editor - Shima <prhshima@gmail.com>
}

In one sense, islands are easy to characterise, the working definition being that they are areas of land wholly surrounded by water. But the edges of that definition are blurred. Complexities arise when we consider areas of sand, rock or coral that are covered at high tide, or that are connected to other land areas at low tide (by sand spits etc.), or that are connected to other land areas by bridges or causeways. Areas submerged at high tide are generally not regarded as islands. Areas linked to others at low tide are an awkward, intermediate category. And areas that have been bridged or linked by causeways are often regarded as having been significantly 'de-islanded' by human engineering. Island Studies has operated with these complexities during its first two decades of operation (taking the establishment of the International Small Islands Studies Association [ISISA] in 1992 as a disciplinary starting point) and has sought to clarify some of its parameters (see, for instance, Baldacchino [ed] [2007] on the issue of bridged islands). But the blurred edges of the definition have been one element that has allowed various critics of Island Studies as a coherent (or, even, worthwhile) field of endeavour to identify that islands share many important characteristics with coastal locations such as ports, estuaries and peninsulas (reflected in the inclusivity of the title and project of the Journal of Marine and Island Cultures, for instance) and/or remote communities in general. These observations are all the more pertinent given that many (especially, but not exclusively) larger islands possess interiors which have highly land-orientated ecosystems, agricultural systems, livelihood networks, infrastructures, social structures and socio-cultural identities.

Along with Island Studies, other disciplines address islands in their nomenclature, most notably, Island Biogeography. The latter field was initiated by McArthur and Wilson in the early 196os and was comprehensively explicated in their 1967 book The Theory of Island Biogeography. 'While conventional islands (ie bodies of land bounded by water) were core to the development of the theory, the same approaches to comprehending, evaluating and predicting the dispersal of species was also applied to other land areas that were 'islanded' by geo-physical features - such as isolated mountain valleys or ecosystems dependent on isolated water features in arid environments. As the field developed, particularly from the 1980 os on, an increasingly functional address to issues of species and habitat conservation led to actual islands being effectively de-centered in favour of a more holistic model that looked at the characteristics of both classic islands and "habitat islands". Whittaker and Fernandez-Palacios (2007) have characterised the latter as occurring in two forms, "Patches of distinct terrestrial habitat isolated by a hostile matrix" and "Marine habitat

\footnotetext{
${ }^{1}$ See Wilson (2010) for an account of the early development of the theory.
} 
islands". They identify the former as including both "mountain tops surrounded by desert" and "woodland fragments surrounded by agricultural land" and expand the frame to encompass far smaller spatial aggregates, such as the isolated micro-habitats of "Thistle heads in a field" (ibid: 11). Such extreme expansions of the notion of islandness have led a number of researchers and theorists to increasingly prefer an alternative term, 'Insular Biogeography', which is now largely interchangeable with the better-known term 'Island Biogeography'. ${ }^{2}$ A similar approach has been evident in areas of socio-economic geography and political science that have identified islands as locations evidencing aspects of insularity shared with other (non-island) insular locations. Such a consideration has also informed discussions within Shima, with authors such as Taglioni (2011) critiquing established definitions of islands and advancing working definitions for quintessential small islands (of the type frequently case studied in articles in the Island Studies Journal and Shima) as "small insular spaces".

From its earliest stages, Shima has approach the issue of islands and islandness from a socio-cultural viewpoint and has addressed insularity as one aspect of this. Indeed, the publication's title flagged its intentions and orientation from the outset. As Suwa elaborated in the first article published in the journal (2007), his essay and the journal's broader project has attempted to articulate "the agency of social groups on islands in creating the 'islandness' of their societies and locales in a manner that will illuminate the study of island cultures" (2006: 6). Suwa set out to accomplish this by focusing on the complex notion of shima in Japanese culture. The term has a dual meaning, referring both an island as a geographical feature and "a small but densely cultured territory (or other community that is also conceived as insular" (ibid). As he notes:

The latter expresses the manner in which local people imagine communal space as if it were an island and, at the same time, that all communal spaces are mimeses of islands. The idea of shima, in this regard, becomes a key for exploring the idea of island as embedded in cultural formations. Islands are, in this regard, 'cultural landscapes' where imagination takes forms of reality... Islands as works of imagination and as geographical features become a mirror to each other. Islands are an event. (ibid)

The crucial aspect of Suwa's emphasis is that the imagination (and subsequent representation) of islands is not an incidental aspect of human habitation of them but rather one that derives from subsistence and livelihood activities enacted upon them:

The concept of shima has the potential for formulating alternative ideas of islands as cultural landscapes because of its inherently cultural approach to Island Studies [and because it has been] developed within a larger perspective of livelihood... Together with imagination, livelihood provides the essence of cultural landscapes... In this sense, the 'island' is a work of imagination derived from lived experience and memory in which the island landscape is a product of natural and human environments interacting with each other. (ibid: 6-7)

\footnotetext{
2 'Insular Biogeography' has been used since the 1960s (see for example, Whitehead and Jones, 1968) but has gained significant traction in recent decades as the field has shifted from addressing classic geographical islands to fragmented eco-systems of various kinds.
}

Shima: The International Journal of Research into Island Cultures Volume 10 Number 12016 
Complementing Suwa's final characterisation of how the imagination of islands operates from an interior viewpoint, Shima has been concerned from its earliest stages to analyse the representation of islands and islandness in cultural media. Articles addressed to this topic have largely eschewed attempts to characterise whether particular islands and island societies have been accurately represented (however that might be understood) and have instead looked at how various representations create cultural forms, paradigms and folkloric perceptions of perceiving and/or inhabiting islands. In this matrix, the imagination of home and other islands by islanders is often just as complex and contentious as those provided by outsiders. Indeed, as Fitzgerald documented in a recent article (2014), cultural producers from one insular archipelagic location, the Outer Hebrides, figuratively re-imagined an even more remote location, Rockall, in order to reflect upon their upbringing in the former during a period of regional modernisation. ${ }^{3}$

The imagination of islands takes various forms. A number of articles recently published in Shima have investigated a particular imagination of island insularity and autonomy through the proclamation of micro-national status for a number of (mostly minuscule) island communities. ${ }^{4}$ The authors of the articles concerned illustrate the manner in which the mere representation of a location as a micronation causes complex patterns of representation and interaction with various legal and legislative systems that can be represented in the media and 'played out' in various scenarios, including military ones. The putative micronations addressed in the articles comprise both conventional islands, fixed marine platforms represented as islands (eg Italy's 'Rose Island'), floating marine platforms ('New Atlantis' in the Caribbean) and sand banks placed on shallow reefs (The 'Republic of Minerva' near Tonga in the South Pacific'). ${ }^{6}$ The commonalities between these ventures transcend their different physical-geographical natures and merit their consolidated analysis, irrelevant of the manner in which they sprawl across established definitions of islands and Island Studies. Echoing the recasting of Island Biogeography as the more inclusive field of Insular Biogeography referred to above, it is also pertinent to identify that continental micronations, which almost always comprise landlocked enclaves within established nation states, are effectively 'land islands'. Indeed this condition is also one that pertains to aspects of shattered and/or contested ethnic aggregations within nation states more broadly. ${ }^{7}$ In such contexts, micronationality might best be understood as a protracted form of performance and its performance on islands might similarly be perceived to perform these spaces - ie to create islandness - in a manner akin to the chorographic aspects identified by Maxwell (2012).

Along with issues of insularity, livelihood and imagination, there are also aspects of

\footnotetext{
${ }^{3}$ See Royle (2014).

${ }^{4}$ See this material aggregated as 'Articles on Micronationality' at http://www.shimajournal.org/

${ }^{5}$ See Cerviere (2009).

${ }^{6}$ See Hayward (2014) for discussion of these.

${ }^{7}$ Artist Julien Boussac produced a particularly vivid expression of this in his 2009 map of Palestinian areas within/occupied by Israel, represented as an 'interior archipelago'. See: 'L'archipel de Palestine orientale: http://: www.lethist.lautre.net/cartographie_du_virtuel.htm - accessed June 4th 2015
}

Shima: The International Journal of Research into Island Cultures Volume 10 Number 12016 
Whittaker and Fernandez-Palacios's previously mentioned typology of islands that merit further reflection. The authors' subset of "marine habitat islands" is highly pertinent. In the authors' formation, this includes:

- $\quad$ The fringing reef around an isolated oceanic island

- Coral reefs separated from other reefs by isolated stretches of seawater

- Seamounts (submerged or not yet emerged mountains below sea level)

- Guyots (submerged flat-topped former islands, i.e. a type of seamount) $(\text { 2007: 11 })^{8}$

Attempts to characterise the nature of various subsurface eco-systems are particularly salient for discussions in Shima concerning the concept of the aquapelago. ${ }^{9}$ The journal's attempts to theorise and debate the integration of marine and terrestrial areas with particular communities have marked its most original contribution to Island Studies to date, expanding the area of focus from islands themselves to integrated terrestrial and marine spaces. One area that is ripe for research, appraisal and evaluation is the manner in which seamounts (such as the Ewing and Malloy seamounts off the south western coast of Africa or the Grand Banks of Newfoundland) have formed the nuclei of aquapelagic assemblages at various historical moments. Indeed, with regard to the latter, since the initial settlement of Newfoundland by the British was primarily undertaken to support the Grand Banks fishery, it is possible to see human livelihood activity on the Grand Banks as 'seeding' an aquapelago that extended to the coast of Newfoundland (rather than vice versa).

Of late, a number of writers have sought to analyse the manner in which aquapelagic sensibilities are manifest in particular localised forms of culture. Dick (2015), for instance, provides a persuasive case study of Vanuatu women's water splashing performances that focuses on the haecceity of the practice in particular points within an aquapelagic nexus. Pugh (2016) develops a similar focus, drawing on the "relational turn" that has begun to emerge in Island Studies (in synch with "associated fields, including oceanic and ship geographies" [2016: 2]), to present and contextualise a case study of the Barbadian 'Landship' tradition. Seeking to encourage increased dialogue between the disciplinary areas itemised above, Pugh asserts that his case study:

foregrounds how islands, oceans and ships should not always be reductively conceptualized in isolation, because they are often inextricably interwoven into complex, multifaceted and shifting arrays of relations and assemblages. (ibid)

These issues are indeed crucial to the project of Island Studies. Reflecting this, and the profound nature of the "relational turn" involved in moving away from rigid geotopographical reference points, the call for papers for this special issue of Shima, designed to commemorate the journal's first decade of publication, met with mixed responses. While some established Island Studies scholars promptly submitted proposals, others cautioned about the risk of destabilising Island Studies by stretching its central definition and framework.

\footnotetext{
${ }^{8}$ While pertinent, this list is not exhaustive (with a notable omission being the isolated temperature and species 'hot-spots' occurring around volcanic vents in deep water locales).

${ }^{9}$ See Hayward (2012a and 2012b) and Fleury (2013).
}

Shima: The International Journal of Research into Island Cultures Volume 10 Number 12016 
The call for contributions to this special 'Almost Islands' issue of Shima originated from discussions I had with experienced Island Studies scholars Ilan Kelman, Grant McCall and Stephen Royle about the topic and its pertinence for Shima and resulted in a call for papers being issued with the following explanatory preface:

\begin{abstract}
Recent postings on the SICRI discussion list have expressed interest in various types of 'almost islands', ie locations that may effectively be regarded as islands due to aspects of their locations and/or due their social and/or political separation from proximous communities and/or political entities. The French term for peninsulas - presqu'iles (literally, 'almost islands') concisely expresses the conditions of various peninsular locales and, in particular, areas connected by isthmuses (effectively 'land bridges' to adjacent coastlines). Paradigmatic presqu'iles of this kind include Gibraltar, to the south of Spain (where geography and the contemporary political situation converge to create the 'almost') and Jaffna, in northern Sri Lanka (which recently served as a stronghold of Tamil separatism). Echoing discussions of the Japanese concept of shima (which refers to both islands and discrete, bounded communities more generally); various (non-peninsular) locations may also have island-ish attributes (the many isolated communities of the Papua New Guinea highlands being one of the most obvious examples of geographical 'islanding' and Cold-War era West Berlin, one of the most obvious recent examples of political isolation). (SICRI mailing list email, 8.8.13)
\end{abstract}

Along with Fleury and Raoulx's extended discussion of the two French terms for peninsulas (presqu'iles and péninsules), the submissions accepted for publication in this issue address locations that are 'almost islands' by virtue of both geography and related political, social and/or infra-structural aspects - Gibraltar, Baja California, Sakurajima, the peninsular cities of Zadar and Trogir and the Otago and Dudley peninsulas. Their islandish identities are created by both the marine spaces that border substantial parts of their terrain and a sense of islandness resulting from either difference from adjacent locales and/or impediments to easy intercourse with them. Reflecting on these, Fleury and Raoulx provide insightful discussions of the manner in which notions of islandness and presqu'îléité represent imaginations of location and local identity (aspects also discussed in Anderson's article on Baja California with regard to the Spanish notion of aislamiento).

If Island Studies is to retain relevance as a field not only addressed to itself and its own institutions and orthodoxies (and thereby suspended in something of a narcissistic state) but also of relevance to other disciplines, communities and broader debates; it needs to reappraise its rationale and its 'edges'. Purity may have been a sound and strategic move in the discipline's youth but plurality and openness to discussion outside of rehearsed orthodoxies is a more productive turn as the field's founding publications (Island Studies Journal and Shima) enter their second decades and as new ones, such as Urban Island Studies emerge. The latter publication, in particular, emerges from the 'Island Cities and Urban Archipelagos' (ICUA) network, which recalls the expanded notion of Island Biogeography discussed above through its address to "metaphorical islands", which it itemises as "archipelago cities, exclusionary enclaves, gated communities, immigrant detention centres, isolated villages and pariah states" (ICUA, 2015: online). This issue of Shima is one modest contribution to such debates, 'rattling the cage' of delimited

Shima: The International Journal of Research into Island Cultures Volume 10 Number 12016 
Islandness and providing insights into it. The intention is not to undermine and/or dissolve Island Studies as a field but rather to enhance its imagination and vision. Underlying the issue is a concern to foster research and discussion that interrogates basic assumptions and orthodoxies and to create materials, projects and perspectives that can engage wider communities. The journal invites feedback and/or article submissions addressing the topics and debates profiled in this Introduction and explicated in the articles in this and previous issues.

\section{BIBLIOGRAPHY:}

Anderson, Ryan (2016) 'Islands within an almost island: History, myth and aislamiento in Baja California, Mexico', Shima: the International Journal of Research into Island Cultures v1o n1: 33-47

Baldacchino, G (ed) (2007) Bridging Islands: The Impact of Fixed Links, Charlottetown: Acorn Press

Cerviere, G (2009) 'The Rose Island', Abitare website: http://www.abitare.it/en/landscape-2/lisoladelle-rose/ - accessed February 2014

Dick, T (2015) 'Chorographing the Vanuatu Aquapelago', Shima: the International Journal of Research into Island Cultures v9 $\mathrm{n} 2:$ 1-22

Fitzgerald, J (2014) "'Halfway" Island: The Creative Expression of Identity Markers within The Band from Rockall Project', Shima: the International Journal of Research into Island Cultures v8 n2: 89-104

Fleury, C (2013) 'The Island/Sea/Territory Relationship: Towards a broader and three dimensional view of the Aquapelagic Assemblage', Shima: the International Journal of Research into Island Cultures v17 n1: 1-13

Fleury, C and Raoulx, B (2016) 'Toponymy, Taxonomy and Place: Explicating the French concepts of presqu'île and péninsule', Shima: the International Journal of Research into Island Cultures v1on1: 8-20

Gold, P (2016) 'Gibraltar - a paradigmatic presqu'ile?', Shima: the International Journal of Research into Island Cultures v10 n1: 21-32

Hayward, P (2012a) 'Aquapelagos and Aquapelagic Assemblages' Shima: The International Journal of Research into Island Cultures v6 n1: 1-10

----- (2012b) 'The Constitution of Assemblages and the Aquapelagality of Haida Gwaii' Shima: The International Journal of Research into Island Cultures v6 n2: 1-8

---- (2014) 'Islands and Micronationality: An Introduction', Shima: The International Journal of Research into Island Cultures v8 nı: 1-8

ICUA (2015) 'Island Cities and Urban Archipelagos' website: http://www.islandcities.org/ - accessed March 3rd 2015

Johnson, H and Kuwahara, S (2016) 'Sakurajima: Maintaining an Island Essence', Shima: the International Journal of Research into Island Cultures v1o n1: 48-66

MacArthur, R and Wilson, E.O (1967) The Theory of Island Biogeography, Princeton: Princeton University Press

Maxwell, I (2012) 'Seas as Places: Towards a maritime chorography', Shima: The International Journal of Research into island Cultures v6n2: 22-24

Shima: The International Journal of Research into Island Cultures Volume 10 Number 12016 


\section{Hayward - Towards an expanded concept of Island Studies}

Mendas, Z (2016) 'Historico-Economic traces in the peninsulas/cities of Zadar and Trogir', Shima: the International Journal of Research into Island Cultures v10 n1: Shima: the International Journal of Research into Island Cultures v10 n1: 85-108

Nash, J (2016) The Dudley Peninsula: Linguistic Pilgrimage and Toponymic Ethnography on an 'almost island', Shima: the International Journal of Research into Island Cultures vio n1: 109-115

Potiki, M (2016) 'The Otago Peninsula, A Unique Identity', Shima: the International Journal of Research into Island Cultures v10 n1: 67-84

Pugh, J (2016) 'The relational turn in island geographies: bringing together island, sea and ship relations and the case of the Landship', Social and Cultural Geography (in press)

Suwa, J (2007) 'The Space of Shima', Shima: The International Journal of Research into island Cultures vini: 6-14

----- (2012) 'Shima and Aquapelagic Assemblages: A Commentary from Japan', Shima: The International Journal of Research into island Cultures v6n2: 12-16

Taglioni, F (2011) 'Insularity, Political Status and Small Insular Spaces', Shima: The International Journal of Research into island Cultures v6n2: 45-67

Whitehead, D and Jones, C (1968) 'Small Islands and the Equilibrium Theory of Insular Biogeography', Evolution v23 n1: 171-179

Whittaker, R and Fernandez-Palacios, J.M (eds) (2007) Island Biogeography: Ecology, Evolution and Conservation, Oxford: Oxford University Press

Wilson, E.O (2010) 'Island Biogeography in the 1960s: Theory and Experiment', in Losos, J.B and Ricklefs, R.E (eds) The Theory of Island Biogeography Revisited, Princeton: Princeton University Press: 1-12 